\title{
firIISGUC.ORG
}

"İȘ, GÜC̣" ENDÜSTRi iLIȘKiLERi VE INSAN KAYNAKLARI DERGisi

"IS, GUC" INDUSTRIAL RELATIONS AND HUMAN RESOURCES JOURNAL

\section{Çalışanların Nepotizm ve Örgütsel Adalet Algılamaları:Orta Anadolu Bölgesinde Bir Aile İşletmesi Uygulaması}

Workers' Nepotism And Their Organizational Justice
Perceptions: Application Of A Family Business In
Central Anatolian Region

\section{Korhan KARACAĞOĞLU}

Yrd. Doç. Dr. Nevşehir Üniversitesi

İktisadi Ve İdari Bilimler Fakültesi

İşletme Bölümü

\section{Derya YÖRÜK}

Yüksek Lisans Öğrencisi, Nevşehir Üniversitesi Sosyal Bilimler Enstitüsü, İşletme Anabilim Dalı

Temmuz/July 2012, Cilt/Vol: 14, Sayı/Num:3, Page: 43-64 ISSN: 1303-2860, DOI: 10.4026/1303-2860.2012.0205.x

Makalenin on-line kopyasına erişmek için:

http://www.isguc.org/? $\mathrm{p}=$ article\&id $=489 \&$ vol $=14 \&$ num $=3 \&$ year $=2012$

To reach the on-line copy of article:

http://www.isguc.org/? $\mathrm{p}=$ article\&id $=489 \&$ vol=14\&num=3\&year=2012

Makale İçin İletişim/Correspondence to: 
(c) 2000- 2012

“İşGüç” Endüstri İlişkileri ve İnsan Kaynakları Dergisi

"İşGüç" Industrial Relations and Human Resources Journal

Temmuz/July 2012, Cilt/Vol: 14, Say1/Num: 3

ISSN: 1303-2860, DOI: 10.4026/1303-2860.2012.0205.x

İş,Güç, Endüstri İlişkileri ve İnsan Kaynaklanı Dergisi, yılda dört kez yayınlanan hakemli, bilimsel elektronik dergidir. Çalışma hayatına ilişkin makalelere yer verilen derginin temel amacı, belirlenen alanda akademik gelişime ve paylaşıma katkıda bulunmaktadır.

İş, Güç, Endüstri İlişkileri ve İnsan Kaynakları Dergisi, 'Türkçe' ve 'İngilizce' olarak iki dilde makale yayınlanmaktadır. Dergi ulusal ve uluslar arası birçok indekste taranmaktadır. (CABELLS DIRECTORY, EBSCO SOCINDEX , INDEX ISLAMICUS, INDEX COPERNICUS, WORLDWIDE POLITICACAL SCIENCE ABSTRACTS, SOCIOLOGICAL ABSTRACT, ULAKBIMM SOSYAL BİLIMLER VERİTANI, ASOS INDEX)

\section{Editör/Editor-in-Chief}

Aşkın Keser (Uludă̆ University)

Editör Yardımcılarn/Co-Editors

K.Ahmet Sevimli (Uludağ University)

Gözde Yilmaz (Marmara University)

Uygulama/Design

Yusuf Budak (Kocaeli Universtiy)

\section{Tarandiğı Indeksler}

ASOS INDEX

\section{CABELLS DIRECTORY}

EBSCO SOCINDEX

Index ISLAMICUS

Index COPERNICUS

Sociological Abstract

ULAKBİM Sosyal Bilimler Veritan

Worldwide Political Science Abstracts
Yayın Kurulu / Editorial Board

Dr. Erdem Cam (ÇASGEM)

Dr. Zerrin Firat (Uludă̆ University)

Doç. Dr. Aşkın Keser (Uludağ University)

Prof. Dr. Ahmet Selamoğlu (Kocaeli University)

Yrd. Doç. Dr. Ahmet Sevimli (Uludă̆ University)

Doç. Dr. Abdulkadir Șenkal (Kocaeli University)

Doç. Dr. Gözde Yilmaz (Marmara University)

Dr. Memet Zencirkıran (Uludă̆ University)

Uluslararası Danışma Kurulu / International Advisory Board Prof. Dr. Ronald Burke (York University - CA)

Assoc. Prof. Dr. Glenn Dawes (James Cook University - AU)

Prof. Dr. Jan Dul (Erasmus University - NL)

Prof. Dr. Alev Efendioğlu (University of San Francisco - USA)

Prof. Dr. Adrian Furnham (University College London - UK)

Prof. Dr. Alan Geare (University of Otago - NZ)

Prof. Dr. Ricky Griffin (TAMU-Texas AEM University - USA)

Assoc. Prof. Dr. Diana Lipinskiene (Kaunos University - LT)

Prof. Dr. George Manning (Northern Kentucky University - USA)

Prof. Dr. William L. Murray (University of San Francisco - USA)

Prof. Dr. Mustafa Özbilgin (Brunel University - UK)

Assoc. Prof. Dr. Owen Stanley (James Cook University - AU)

Prof. Dr. Işık Urla Zeytinoğlu (McMaster University - CA)

Ulusal Danışma Kurulu / National Advisory Board

Prof. Dr. Yusuf Alper (Uludă̆ University)

Prof. Dr. Veysel Bozkurt (İstanbul University)

Prof. Dr. Toker Dereli (Işık University)

Prof. Dr. Nihat Erdoğmuş (Şehir University)

Doç. Dr. Mustafa Kurt (Yalova University)

Prof. Dr. Ahmet Makal (Ankara University)

Prof. Dr. Süleyman Özdemir (İstanbul University)

Prof. Dr. Ahmet Selamoğlu (Kocaeli University)

Prof. Dr. Nadir Suğur (Anadolu University)

Prof. Dr. Nursel Telman (Maltepe University)

Prof. Dr. Cavide Uyargil (İstanbul University)

Prof. Dr. Engin Yildirm (Constitutional Court of Turkey)

Doç. Dr. Arzu Wasti (Sabancı University)

Dergide yayınlanan yazılardaki görüşler ve bu konudaki sorumluluk yazarlarma aittir.

Yayınlanan eserlerde yer alan tüm içerik kaynak gösterilmeden kullanılamaz.

All the opinions written in articles are under responsibilities of the outhors.

The published contents in the articles cannot be used without being cited. 


\title{
Çalışanların Nepotizm ve Örgütsel Adalet Algılamaları: Orta Anadolu Bölgesinde Bir Aile İşletmesi Uygulaması
}

\author{
Workers' Nepotism And Their Organizational Justice Perceptions: \\ Application of A Family Business In Central Anatolian Region
}

\author{
Korhan KARACAOĞLU \\ Yrd. Doç. Dr. Nevşehir Üniversitesi \\ İktisadi Ve İdari Bilimler Fakültesi \\ İşletme Bölümü
}

\author{
Derya YÖRÜK \\ Yüksek Lisans Öğrencisi, Nevşehir \\ Üniversitesi Sosyal Bilimler Enstitüsü, \\ İşletme Anabilim Dalı
}

\begin{abstract}
Özet
Bu araştırmanın amacı, çalı̧̧anlar arasındaki nepotizm ve örgütsel adalet algılamaları arasındaki ilişki ve etkileşimin belirlenmesinden oluşmaktadır.

Araştırmanın örneklemi Orta Anadolu Bölgesinde faaliyet gösteren bir aile işletmesinin 129 mavi yakal çalı̧andır. Araştırmada kullanılan veriler, iki ölçekten oluşan anket yardımı ile toplanmıştır. Araştırma bulgularına göre, çalışanların nepotizm ve örgütsel adalet algılamaları arasında ters yönlü fakat düşük bir ilişkinin olduğu, regresyon analizi sonuçlarına göre ise, örgütsel adalet algisı üzerinde, nepotizmin boyutlarından terfide kayırmacillk ve işe alma sürecinde kayırmacıllk boyutlarının etkili olduğu tespit edilmiştir. Ayrıca araştırmada, çalı̧̧anların gerek nepotizm ve gerekse örgütsel adalet algilamalarının demografik değişkenlere göre her hangi bir farklilık göstermediği sonucuna ulaşılmıştır.
\end{abstract}

Anahtar Kelimeler: Nepotizm, Örgütsel Adalet, Aile İşletmeleri, İşe Alım Sürecinde Kayırmacılık, Terfide Kayırmacilik

\footnotetext{
Abstract

The aim of this research is to determine the relationship and interactions between workers' nepotism and their organizational justice perceptions.

The sample of this research is 129 blue color workers of a family business in Central Anatolian Region. Data used in this research was gathered by a questionnaire composed of two scales.

According to research findings, it was determined that there is a negative but low correlation between the workers' nepotism and their organizational justice perceptions. On the other hand, according to regression analysis findings, recruitment and promotion processes and the dimensions of the nepotism are effective on the organizational justice perception. Also, it was found that nepotism and organizational justice perceptions didn't vary in terms of demographic variables.
}

Keywords: Nepotism, Organizational Justice, Family Businesses, Recruitment Process of Nepotism, Promotion Process of Nepotism 


\section{Giriş}

Nepotizm en öz şekliyle örgütte akrabaların istihdam edilmesi olarak tanımlanmaktadır. Nepotizm uygulamalarının olduğu örgütlerde İnsan Kaynakları Yönetimi (İKY) uygulamalarının bağımsız bir şekilde yürümesi de oldukça zordur. Ayrıca nepotizm uygulamalarının olduğu örgütlerde çalışanlar; yeterince motive olamaz, iş tatminleri düşer, işi bırakma ve örgüt hakkında şikâyette bulunma eğilimi artar. Nepotizm uygulamaları çalışanların özellikle ücret, ödüller vb. örgütsel çıktıların paylaşımı anlamına gelen dağıtım adaleti noktasindan olumsuz değerlendirmede bulunmalarına zemin hazırlayabilir.

Örgütlerdeki adalete yönelik uygulamalar çalışanların performansını, verimliliğini, bağlılığını ve iş tatminlerini artırırken, özellikle İKY ile ilgili nepotizm benzeri adalet algilamalarını sarsicı uygulamalar; çalışanlarda verim düşüklügüune, işten ayrılma niyetinin artmasına ve yabancilaşma gibi olumsuz örgütsel sonuçlara neden olabilmektedir. Nepotizm sadece örgüt ve onun halkla ilişkileri, imajı, yönetim geliştirme ve kontrol açısından bir sorun değil, yönetim katında akrabalık ilişkilerine sahip olma isteği olan yöneticiler için de bir sorundur. Her ne kadar işletmelerin büyümeleri sonucu nepotizmin azalacağ gerek Amerika ve gerekse Avrupa'da halen canlılığını koruduğu ve varlığını devam ettirdiği görülmektedir. Aynı şekilde nepotizmin az gelişmiş ülkeler açısından önemli bir sorun olduğu da belirtilmektedir (Abdalla ve diğ., 1995: 554).

İlgili uluslararası yazında örgütsel adalet ve nepotizm ile ilgili oldukça geniş bir literatür bulunmakla beraber, özellikle Türkçe çalışmalarda her iki kavramın bir arada incelenmesinin önemi belirtilmekle yetinilmiş ancak Büte ve Tekarslan'ın (2010) işlem adaleti boyutu ile ele aldığı görgül araştırma d1şında, nepotizm ve örgütsel adalet olgusunu bir arada inceleyen her hangi bir uygulamalı araştırmaya rastlanılmamıştır.
Bu araştırmada Orta Anadolu Bölgesinde faaliyette bulunan bir aile işletmesinde çal1şanların nepotizm ve örgütsel adalet algılamaları arasındaki ilişki/etkileşim ortaya konulmaya çalıșılacaktır. Bu bağlamda araştırmanın birinci bölümünde nepotizm ve örgütsel adalet kavramları ele alınırken, ikinci bölümünde görgül araştırma ve bunun sonuçları ortaya konulacaktır. Sonuç bölümünde ise araştırma bulgularının yorumu ve bazı önerilerde bulunulacaktır.

\section{Kuramsal Çerçeve}

\subsection{Nepotizm Kavramı}

Nepotizm, hem kamu hem de özel sektör işletmelerinde karşılaşılan önemli sorunlardan biridir (Bayhan, 2002: 1-13). Webster's sözlügüunde nepotizm, yeğen veya akrabaların kabiliyetleri yüzünden değil de sırf akrabalık ilişkileri yüzünden önemli pozisyonlara getirilmek suretiyle iltimas görmeleri olarak tanımlanmaktadır (Merriam-Webster, 2000; Wong ve Kleiner, 1994: 10). Nepotizm; bir bireyin bilgi, beceri, yetenek, eğitim düzeyi ve deneyimlerine bakılmaksızın işe alınması, terfi ettirilmesi, diğer çalışanlardan daha uygun çalışma koşullarında çalıştırılması gibi etkenleri akrabalık ilişkileri sayesinde elde etmesi olarak tanımlanmaktadır (Özsemerci, 2003: 20). Kavramin temelini kişinin bulunduğu konumu akrabaları yararına istismar etmesi oluşturmaktadır. "Kin selection" veya akraba kayırma insan doğasında (bazı biyologlara göre hayvanlarda da) var olan bir içgüdüdür. Ancak nepotizm; keyfi, duygusal veya içgüdüsel bir davranış olarak değil, rasyonel ve seçilmiş bir davranış ve bir yönetim biçimi olarak kabul edilmektedir (Özler ve diğ., 2007:437-438). Nepotizmde bir kişinin işletmede istihdam edilmesinde ve yükseltilmesinde liyakat (beceri, kabiliyet, başarı, eğitim düzeyi vb.) ilkeleri dikkate alınmamakta sadece akrabalık bağ 1 dikkate alınmaktadır (İyiişleroğlu, 2006: 44). Nepotizm kavramının Latince "Nepot" sözcüğünden geldiği ve bunun İngilizce karşıllı̆̆ının Nephew (yeğen) olduğu değişik çalışmalarda 
ifade edilmektedir (Garih, 2000:79; Abdalla ve diğ., 1998:555; Ford ve McLaughin, 1985:57). Nepotizm kavraminin genellikle olumsuz bir çağrışım bırakmasının nedeni Rönesans döneminde bazı Papa'ların niteliklerini göz önüne almaksızın yeğenleri için üst düzey işler bulma eğilimlerine dayanmaktadır. Bu dönemdeki uygulamalar kilisenin etkinliğini artırırmış ve yeğeni olmayan kişilerin morallerini olumsuz yönde etkilemiştir (Ford ve McLaughin, 1985: 57). 2000 yılında Amerika Birleşik Devletleri başkanllk seçiminde iki köklü ailenin oğullarının yarışması nepotizmin ne kadar yaygın olduğunun ispatıdır. Günümüzde nepotizmi politika, yayıncilık ve otomobil yarışları gibi birçok alanda görmek mümkündür (Joffe, 2004: 74).

İş hayatında bireylerin belirli görevlere gelmesinde ve statü değiştirmesinde kendi çaba ve yetenekleri yerine, akrabalık ilişkilerini kullanmaları, kendi açılarından bir zafiyete; iş ortamı açısından ise göreve gelmede başarı ve yetenek ölçüt alınmadığından, iş kaybı ve başarısızlığa neden olmaktadır. İşletmeler insan kaynaklarını seçerken adayın işin gerekliliklerine uyumu, eğitim ve deneyim durumu, sektör ve bölüm bilgisi gibi konuları göze almak zorundadırlar. Ancak adayın işletmenin üst düzey yöneticilerinden biriyle veya işletme sahibiyle akrabalık ilişkisi olması, personel seçimi yapan bölümün objektif olamamasına yol açmaktadır (İyiişleroğlu, 2006: 44).

Nepotizm kavramının Türkçede yer yer kayırmacılık kavramı ile eş anlamda kullanıldığı görülmektedir. Ancak kayırmac1lik kavramı, nepotizm kavramindan daha geniş kapsamlıdır ve bünyesinde farklı türler bulundurmaktadır. Bunlar arasında, nepotizmin tanıminda yer alan akraba kayırmacılığın ötesinde, eş-dost, arkadaş, hemşehri, aynı okullu olmak, aynı kökenden olmak, aynı siyasi görüşten olmak gibi benzerlikleri esas alan kayırmacılık biçimleri ön plana çıkmaktadır. Literatürde, tanıdık, eşdost kayırmacılığı için daha çok kronizm terimi; siyasal ve dinsel yandaşlık için patronaj terimi; iktidara ve seçmen kesimlerine yönelik kayırmacılık için ise klientelizm terimi kullanılmaktadır (Aközer, 2003: 14). Sonuç olarak nepotizm kavramı, kişinin kendi güç ve otoritesini kullanmak suretiyle, kendi akraba ve aile fertleri için yeteneklerine bakılmaksızın istihdam olanağı sağlaması durumunu ifade etmektedir (Karakaş ve Çak, 2007: 78). Kayırmacıllkta ise, kişinin kendi akraba ve aile fertleri dişından olan kişilere de fayda oluşturması söz konusudur. Aile üyelerinin iktidar kaybını engellemeye yönelik bir strateji olan nepotizm, demokrasi ve kurumsallaşmanın önündeki en önemli engellerden birisidir. Bununla birlikte nepotizm bir işletmede aile kavgalarına veya nesiller arası çatışmalara, yeterli ve kaliteli yöneticilerin uzaklaşmasına, örgütsel bağl1lığın zayıflamasına ve bu nedenle insan sermayesinin tükenmesine neden olabilmektedir (Özler ve diğ., 2007: 438-439). "Adam kayırmacılık", "kollamacılık", "iltimas", ve "torpil" gibi kavramlarla da eş anlamlı olduğu bilinen kayırmacılıkda örgütsel görevlere yapılan atamalarda "liyakat" ilkesinin yerini, akrabalık, hemşerilik, arkadaşlık, dostluk vb. kişisel faktörlerin alması durumu söz konusudur (Büte 2011: 179). Bu araştırmada kayırmacılık her ne kadar daha genel bir kavram olarak ele alınsa da yer yer nepotizm anlamina gelecek şekilde de kullanilacaktır.

Genel olarak nepotizmden bahsedilirken olumsuz olarak bahsedilir. Fakat olumlu olan yönleri de vardır. Nepotizmin yukarıda bahsedilen birçok olumsuz etkilerinin yanı sira, azda olsa olumlu etkilerinin de olduğunu tespit eden araştırmalar bulunmaktadır. Nepotizmin, özellikle, aile üyeleri üzerinde olumlu etkileri bulunduğu iddia edilmektedir. Örneğin; birçok işletmede çalışanlar kendi işleri olmadığı için yeterince özverili ve istekli çalışmazken, aile üyeleri kendi işletmeleri olduğu için diğer çalışanlara göre daha fazla çalışmakta ve daha fazla özveride bulunmaktadırlar. Aile işletmelerinde örgütün durumunu ve stratejisini iyi bilen profesyonel üst düzey yöneticilerin başka işletmelere transfer olması her zaman 
olasıdır. Ancak, sahip yönetici olan aile üyeleri için böyle bir durum geçerli değildir. Ortak kültür, anlayış ve değer yargılarının aynı örgütte paylaşılması ve bu noktalarda aileden gelen kişilerin avantajlı konumları nedeniyle o örgütte üst düzey yöneticilerin aile üyelerinden atanması (nepotizm) bir avantaj olarak değerlendirilmektedir (İyiisleroğlu, 2006: 47). Özler ve diğ., (2007, s. 438) nepotizmi, aile üyelerinin iktidar kaybını engellemeye yönelik olarak gördükleri bir strateji olarak ifade ederken; Molofsky (1998) nepotizmin daha kısa öğrenme süresi, daha fazla örgütsel bağlılık, daha düşük risk, daha iyi performans, daha az işgücü devrine neden olduğunu; Aranoff ve Ward (1993), nepotizmin kurallara ihtiyaç duyulmadan önce oluşturulacak açık bir iletișime neden olduğunu; Nelton (1998) nepotizmin, işletmelerde yüksek performans, işletmeye uzun süreli bağlılığa neden olacağını; Danco (1982) ise, nepotizmin başarının sürekliliğine yol açacağını ifade etmişlerdir (Büte ve Tekarslan, 2010: 6). Aile işletmelerinin yönetiminde aile üyesi veya üyeleri etkin konumdadır. Bu işletmelerin büyük çoğunluğunda önemli rekabet avantajı olarak aile üyesi olan işgücünün örgüte bağlılığı ve uysallığı ile aile içi bağların güçlü olması gösterilir. Çalışanlar bilgi ve beceriye dayalı bireysel özerkliğe sahip kişiler olarak değil, ailenin koruması altındaki insanlar veya (en iyi ihtimalle) manevi evlatlar olarak görülür. Bundan dolayı, aile üyesi olmayan kişilere duyulan güven eksikliği, bu kişilerin kendilerini daha farklı bir sinıfta görmesine neden olabilmektedir. Bunun sonucunda da aile üyesi olmayan çalışanlarda kayırmacılık alg1sı ortaya çıkabilmektedir (Özler ve diğ., 2007: 444) .

Nepotizm, örgütsel ortamda adaletsizlik algilamalarına neden olduğu için ortadan kaldırılmaya çalışılmaktadır. Ancak Below (2003) "Nepotizme Övgü" adlı yapıtında planlı gerçekleştirilen nepotizm uygulamalarının birçok şirketin başarısının nedeni olduğunu vurgularken, başarısızlığın sebebinin ise nepotizme bağlanmasının çok zorlama bir yaklaşım olacağını belirtmekte- dir. Yazar, nepotizmin imalat sanayi, güvenlik ve itfaiye teşkilatı gibi alanlarda oldukça yaygın rastlanan kurumsallaşmış bir pratik olduğuna değinmektedir (Özler ve diğ., 2007: 437). Örgütlerde tanıdık ve akrabalarla çalışmanın yönetim açısından daha güven veren ve rahat olunmasını sağlayan bir durum olduğu göz önünde bulundurulduğunda, yönetimin ikinci ve üçüncü kuşaklara devredilmesinde bu avantajların nepotist tercihleri ön plana çıkarması doğal karşılanabilir. Aile için işletme metaforik bir imgelemle "çiftliktir". Bu çiftlikteki faaliyetler ailenin gereksinimlerini karşılamak içindir. Ailenin yapısı ve büyüklüğü işletmenin örgüt yapısını ve davranışlarını belirleyen temel faktördür. Bu ekonomik yapı içinde çalışan bireylerin, ailenin ve işletmenin kontrolünü ele geçirmelerini engellemek için "devşirme" veya kiralık işçi statülerinin ötesine geçmelerini önlemek sahip yöneticinin bir sorumluluğu olarak algilanmaktadır. Bu durumdan hareketle nepotizmi tümüyle onaylanan veya onaylanmayan bir olgu olarak görmek yerine olumlu ve olumsuz sonuçlarıyla birlikte değerlendirmek daha isabetli bir yaklaşım olabilir.

Nepotizme, geleneksel ilişkilerin yoğun olduğu piyasa mekanizmasının yeterince gelişmediği ülkelerde daha yaygın olarak rastlansa da gelişmiş ülkelerde de rastlanmaktadır. Nepotizm, monarşi veya krallık gibi bir yönetim pratiğidir, her yönetim uygulamasının yararlı yanları yanında sakıncaları da vardır. Kültürden kültüre bu nepotist yönetim uygulamaları değișkenlik göstermektedir. Söz gelimi Osmanlı İmparatorluğu döneminde Türklerde saltanat önceleri yetenekli, beceri sahibi, bilge ve cesaretli kardeşin tahta geçmesini sağlayan dolay1sıyla olumlu sonuçlar doğuran bir nepotist uygulama iken, İmparatorluğun son dönemlerinde saltanatın yetersiz kişileri ön plana çıkaran olumsuz bir uygulamaya doğru yöneldiği görülmüştür (Özler ve diğ., 2007: 438) .

Modern ve günün iş dünyasının gereklerine uygun bir işletmede işletme sahipleri- 
nin geleneksel yönetim anlayışlarının ve dünya görüşlerinin değişmesi gerekmektedir.

Aile işletmeleri açısından en önemli sorunların başında kurunmsallaş(a)ma gelmektedir. $\mathrm{Bu}$ noktada nepotizm kurumsallaşmanın önündeki en önemli engeller arasındadır. Aile işletmelerinde nepotist uygulamalar ile aile üyelerinin egemenlik ve hükümranlığının sürmesi amaçlanırken, böylelikle işletmenin aileden bağımsız veya ondan daha geniş ve kendine özgü kurumsal bir kimlik kazanmasına izin verilmemekte, tüm paydaşlar gözünde bir güvensizlik algısı yaratılmaktadır. Bu durumun bir sonucu olarak, işletmedeki nitelikli işgücünün uzaklaşması, kurumsal bağlılığın zayıflaması, adaletsizlik algılamalarının yaygınlaşması ve bu nedenle insan sermayesinin tükenmesi ve verimli kullanılamaması gibi sorunlar ortaya çıkabilmektedir.

\section{2. Örgütsel Adalet Kavramı}

Adalet kavramı sosyal bir varlık olan insanın en önemli ihtiyaçları arasında yer almakta ve toplulukları; hak, hukuk, eşitlik gibi kavramların ışı̆̆ında bir arada tutmaktadır. Örgütsel adalet, örgütte çalışan bireylerin o örgüt ile ilgili adalet algısıdır (Kurgun ve diğ., 2010: 173). Örgütsel adalet kavramı temelde Adams'ın geliştirdiği "Eşitlik kuramı" ve Crozby'nin "Göreli Yoksunluk Teorisine" dayanmaktadır. Eşitlik kuramı örgütte alınan dağıtım kararlarına ilişkin olarak bireylerin algıladıkları adillik derecesi ile bireylerin örgütteki adil olmayan durumlar karşısında göstermiş oldukları tepkiler üzerine odaklanmaktadır. Adams'a göre bireyler sürekli ve sonu gelmeyen bir biçimde kendi konumlarını kendileri ile aynı konumda olan farklı kişileri referans alarak karşılaştırmaktadırlar. Bu karşılaştırmalar sonucunda kendilerine haksızlık edildiği düşüncesine sahip olabilirler. Bu düşünceler bireylerin tutumlarını etkileyerek belirli davranışlar geliştirmelerine neden olur. Dolay1sıyla geliştirilen bu davranışlar, diğer bireylere yönelik olabileceği gibi çoğu zaman örgütlere yönelik de olabilmektedir. Buna göre örgütsel adalet, çalışanın işyerindeki uygulamalara ilişkin zihninde oluşturduğu adalet algısıdır (Altıntaş, 2006: 21) . Göreli Yoksunluk Teorisi ise örgütte alt kademelerde çalışanların elde ettikleri kazanımları, üst kademedeki çalışanların kazanımları ile karşılaştırmaları ve bu farklı sınıflar arasındaki karşılaştırmalar sonucunda kendinde algıladığ 1 yoksunluk hissi olarak tanımlanabilir (Carrell ve Dittrich, 1978: 207).

Çalışanların kişisel doyumu ve örgütün etkili bir biçimde işlevlerini yerine getirebilmesi olan örgütsel adalet, doğruluğun iş yerindeki rolü ya da haklılığın korunmasında otoritenin işlevi olarak tanımlanabilir (Özer ve Günlük, 2010: 400). Örgütsel adaletin çalışanların doyumu ve örgütün etkili bir biçimde işlevlerini yerine getirmek için bir gereklilik olduğu ve adaletsizliğin örgütsel bir sorun olarak ele alınması gerektiği sosyal bilimciler tarafından kabul edilmektedir (Greenberg, 1990: 399). Örgüt içerisinde; ücretlerin, ödüllerin cezaların ve terfilerin nasıl yapıldı ğı, bu tür karaların nasıl alındığı veya alınan bu kararların çalışanlara nasıl söylendiğinin, çalışanlarca algılanma biçimi örgütsel adalet olarak tanımlanmaktadır (İçerli, 2010: 69). Genel olarak örgütsel adalet ile ilgili yapılan araştırmalar kendilerine adil davranıldığını düşünen kişilerin örgüte olumlu bir eğilimlerinin olacağ1 ve örgütün yararına davranışlar sergileyeceği görüşünden yola çıkmaktadır (Barling ve Philips, 1993: 649). İnsanlar çevrelerinde olup bitenlerin ne kadar adil olup olmadığını değerlendirmekte ve adaletsiz durumlara tepki vermektedirler. İnsanların bu değerlendirmeyi yoğun olarak yaptıkları yerlerden biri de zamanlarının büyük bir bölümünü geçirdikleri iş yerleridir (Irak, 2004: 26). Dolayısıyla işyerinde oluşacak herhangi bir adaletsiz duruma tepki gösterecek, tutumlarını ve davranışlarını bu doğrultuda yönlendireceklerdir (Kurgun ve diğ., 2010: 173). Bu çerçevede çalışanların geliştirdikleri tutum ve davranışlar, dağıtım ve işlem adaletine karşı geliştirilen iki farklı adalet algısının so- 
nucu olarak görülmektedir. Dağıtım adaleti, gelir, prim, terfi ve sosyal haklar gibi örgütsel kazanımların örgüt genelindeki dağıtımina ilişkin bireylerin algılamış oldukları adillik derecesidir. Bu kaynaklar örgüt içinde oluşturulmuş kaynaklar olduğu kadar, örgüt dışından gelen kaynaklar da olabilir. Bu kaynak bazen maddi imkânlardır, bazen terfidir, bazen sağlanan fiziksel olanaklardır. Bunların örgüt içindeki dağılımina ilişkin kararlar, dağıtım adaletinin kapsamına girmektedir. İşlem adaleti, kaynakların tahsisi ve diğer örgütsel kararların ortaya çıkmasında örgütsel politika ve prosedürlere ilişkin eşitlik algılamasından kaynaklanmaktadır (Williams ve diğ., 2002). İşlem adaleti, örgüt tarafından kararların alınmasında kullanılan süreçlerin adilliğine ilişkin alg1lardır. Örgütsel süreçler, örgütün mevcut kaynaklarının dağıtım yöntemlerini ifade eder. Örgütsel düzeyde gerçekleştirilen işlemler ancak, örgütsel kazanımların bireylere aktarılmasındaki adillik ölçüsünde meşru kabul edilmektedir. İşleme dayalı adalet algısı bir anlamda çalışanların kararların alınma biçimine yönelik tepkidir. İşlem adaletine ilişkin bireylerin oluşturdukları yargıları belirleyen faktörlerden ilki, karar alıcının karardan etkilenen kişilere karşı göstermiş olduğu tavırdır. Karar alıcının karardan etkilenen kişilere karşı dürüst ve nazik davranması, alınan karara karşı zamanında geri bildirimde bulunması, kurallara sayg1 göstermesi şeklindeki tavırları, çalışanların örgüt içi işlem adaletine ilişkin değerlendirmelerinin temel belirleyicileri arasinda yer almaktadır. İşlem adaletine ilişkin yargıları belirleyen ikinci faktör ise karar alıcının alınan kararlarına ilişkin açıklamalarıdır. Alınan kararların dayandı $\breve{g}_{1}$ sebeplere ilişkin açıklamaların yeterliliği ve çalışanlarla samimi bir iletişimin kurulması işlem adaletine ilişkin algıları olumlu yönde etkileyecektir. Dolayısıyla işlem adaleti, örgütsel katılım gibi duygusal, bilişsel ve örgüte yönelik davranışsal tepkilerin bir göstergesi olarak ifade edilebilir. Neticede, dağıtım adaletine ilişkin algıların merkezinde örgütün var olan kaynaklarından bi- reylerin adil bir biçimde faydalandıkları düşüncesi önem kazanırken, işlem adaletine ilişkin algıların merkezinde ise dağıtım kararlarında kullanılan süreçlere ilişkin adalet algısı önem kazanmaktadır (Altıntaş, 2006: 22). Örgütsel adaletin bir başka boyutu etkileşim adaletidir. Bu adalet türünde örgütsel işlemlerin yapılması sırasında amirlerin etkileşim halinde oldukları iş görenlere yönelik davranışlarında saygılı ve eşitlikçi olması vurgulanmak istenmektedir (McDowall ve Fletcher, 2004; Williams ve diğ., 2002). Etkileşim adaleti bireyler arası ilişkilerin daha çok biçimsel olmayan boyutu ile ilgilidir


(2001) etkileşim adaletini enformasyon adaleti ve kişiler arası adalet olmak üzere iki alt başlıkta ele almaktadır. Enformasyon adaleti örgütsel karar ve süreçlere ilişkin işleyiş ile ilgili olmak üzere ilgili kişi veya kişilere bilgilendirmede bulunulmasına ilişkin uygulamaları kapsar. Kişiler arası adalet ise yönetsel uygulamalarda bireylere ne kadar saygılı, nezaketli ve onore edici şekilde davranıldığı ile ilgili adalet algılamalarını içerir.

\subsection{Nepotizm ve Örgütsel Adalet İlişkisi}

Adalet sorunu tüm insan kaynakları uygulamaları içinde en sık rastlanan sorunlardandır. Sözgelimi insan kaynaklarının seçimi ve istihdamında adam kayırma, iltimas veya nepotizm işe alım kararlarında her ne kadar kaçınılması gereken bir hususlar olarak vurgulansa da genellikle kararlarda etkili olmuştur. Bu durum, insan kaynakları yönetimi ilkelerinden eşitlik ve yansızlığın açık ihlali ve örgüt üyeleri arasında oluşacak hakkaniyet ve adalete ilişkin olumsuz alg1lamaların ortaya çıkmasının önemli bir sebebini oluşturacaktır.

Araslı ve. diğerlerine göre İK uygulamalarında nepotizm, etik dıșı bir davranıș olduğu için diğer çalışanlar arasında algılanan adaletin düzeyini olumsuz yönde etkilemektedir (Araslı ve diğ., 2006:305). Asunakutlu ve Avc1 (2010) kayırmacilık alg1sı ile örgütsel adalet algısı arasında ciddi bir ilişkinin olduğuna işaret etmekte ve yapılacak 
araştırmalarda bu iki kavram arasındaki ilişkinin incelenmesini salık vermektedirler (Asunakutlu ve Avc1, 2010: 105).

Birçok aile işletmesi; personel seçim ve değerleme değişkenlerini kullanmaksızın, örgüt içindeki kilit pozisyonlara aile üyelerini getirmektedir. Ancak adil olmayan bu durum, aile üyesi olmayan çalışanlar açısından son derece rahatsız edicidir. Böylece ortaya çıkan adalet ve güven eksikliği, çalışanların iş tatmini, motivasyon ve bireysel performanslarını olumsuz olarak etkilemekte, bu da aile üyesi olmayan çalışanların işletmeden ayrılmasina yol açabilmektedir (Günel, 2005: 31-32).

Keleş ve diğ., (2011) bazı işletmelerce istihdam ve işe yerleştirme gibi İKY uygulamalarında arkadaşlık ve kan bağı ilişkisinin ön planda değerlendirilmesine bağlı olarak işletmedeki diğer çalışanlarda görülecek verim düşüklüğünün sonucunda motivasyon, harmoni ve örgütsel adaletin olumsuz etkileneceğine işaret etmektedir (Keleş ve diğ., 2011: 11). Bir başka araştırmada da İK uygulamalarında nepotizme ilişkin tercihlerin aile üyesi olmayan çalışanlarda; ücret, terfi, değerlendirme ve performansa ilişkin sonuçlar bakımından dağıtım adaleti boyutu ile ilişkili sorunlara neden olabileceğinin altını çizmektedir (Barnett ve Kellermanns, 2006: 841).

Büte ve Tekarslan (2010) tarafından yap1lan araştırmada nepotizmin boyutlarının örgütsel adaletin boyutlarından işlem adaleti ile olan ilişkisine bakılmış ve çalışanlar arasında terfi ve işlem kayırmacılığ arttıkça; işverene güven, işlem adaleti ve iş tatmininin azaldığ 1 bulgusuna ulaşılmıştır (Büte ve Tekarslan, 2010: 14).

\section{3. Çalışanların Nepotizm ve Örgütsel Ada- let Algılamaları Arasındaki İlişkiye Yönelik Görgül Bir Araştırma}

\subsection{Araştırmanın Amacı ve Önemi}

Araştırma, çalışanların nepotizm algılamaları ile örgütsel adalet algilamaları arasında her hangi bir ilişki veya etkileşim olup olmadığ1 sorusundan hareket etmektedir. Öncelikle araştırmaya katılanların, nepotizm ve örgütsel uygulamalarla ilgili adalet alg1lamalarının düzeyi ortaya konulmaya çal1şılmıştır. Buradan hareketle araştırmanın temel amacı, çalışanların, nepotizm ve örgütsel adalet algılamaları arasında nasıl bir ilişki veya etkileşimin olduğunu ortaya koymak ve nepotizm algisının alt boyutlarının örgütsel adalet algılamalarının yordayıcısı olup olmadığını belirlemektir. Ayrıca bu araştırma ile çalışanların demografik özelliklerine göre, nepotizm ve örgütsel adalet düzeyleri yönünden farklılık gösterip göstermedikleri ortaya konulmaya çalışılmaktadır. Elde edilecek sonuçların işletme yöneticileri ile paylaşılması sonucunda işletmede gerçekleşen faaliyet ve uygulamaların çalışanlarca ne şekilde algılandığının görülebilmesi ve bu sayede işletme yöneticilerinin çalışanların daha verimli ve motive olabilmeleri için nasıl uygulamalar içinde olabileceklerine yönelik olarak onlara katkı sağlanması bu çalışmanın dolaylı amaçları arasında sayılabilir.

Türkçe alan yazına bakıldığında nepotizm ile ilgili görece sinırlı fakat örgütsel adalet ile ilgili zengin bir literatürün varlığ 1 tespit edilmiştir. Ancak literatürde söz konusu kavramların ayrı ayrı ve daha başka konularla ilişkili olarak ele alındığı sadece Büte ve Tekarslan'ın (2010) çalıșmalarının kavramları bir arada ele aldığ 1 bilgisine ulaşılmıştır. Zira alan yazında önemli bir yeri olan Asunakutlu ve Avcr (2010) ilgili literatürün zenginlik kazanabilmesi için yaptıkları önerilerinde özelikle nepotizm ile örgütsel adaletin birlikte incelenmesi üzerinde durarak konunun araştırılmasının önemine işaret etmişlerdir.

\subsection{Araştırmanın Kapsam ve Kısıtları}

Araştırma bazı kapsam ve kısıtlılıklara sahiptir. Araştırma konu kapsamı itibari ile örgütsel adalet algılamaları üzerinde nepotizme ait boyutların etkisini ele alan bir çalışmadır. Bu haliyle araştırma, kavramlar arasındaki ilişkileri ortaya koyacak şekilde 
geliştirilmiş hipotezlerin test edilmesi ve ilgili örneklem kitlesine ilişkin betimleme/durum tespitinde bulunmayı amaçladığından, hipotetik-tanımlayıcı araştırma türü kapsamına girmektedir. Çalışmanın analiz düzeyi Orta Anadolu bölgesindeki bir aile işletmesi ve analiz birimi ise bu işletmede çalışan 129 mavi yakalı personeldir. Çalışma Haziran 2011 döneminde yapıldığından yer ve zaman kısıtı bakımindan belirtilen yer ve tarihte elde edilen bulguları yansitmaktadır. Dolayısıyla elde edilen sonuçlar söz konusu işletme çalışanları ile sinırlı olup kapsamlı genellemelerde bulunmaya olanak vermemektedir. Ayrica anket uygulaması işletme yönetiminin izni ve inisiyatifi ile gerçekleştiğinden yanıtlay1cıların kendileri üzerinde bir araştırma yapıldığını bilmelerinden dolayı howthorne etkisine maruz kalabilmeleri de olasılık dâhilindedir. Fakat bu türden etkileri en aza indirebilmek için, yanıtlayıcılardan anketleri yanitlarken isim belirtmemeleri istenmiş ve araştırma sonuçlarının ișe ilişkin değerlendirmelerde kesinlikle kullanılmayacağ 1 belirtilmiştir. $\mathrm{Bu}$ araștırmada elde edilen veriler, araştırmaya katılanların öznel görüşlerine dayandığı için sonuçların nesnelliği ve genellenebilirliği de bu kısıtlar çerçevesinde değerlendirilmelidir.

\subsection{Araştırmanın Modeli ve Hipotezleri}

Şekil 1'deki araştırma modelinde örgütsel adalet bağımlı değişken ve bunu yorda-

\section{Şekil 1}

Araştırma Modeli

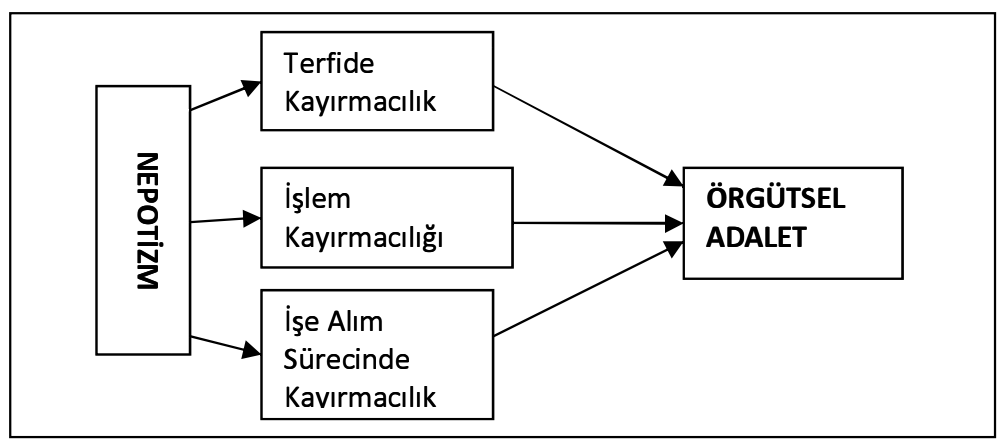

yıcı olarak belirlenen ve nepotizmi oluşturan; terfide kayırmacılık, işlem kayırmacılığ ve işe alım sürecinde kayırmacılık boyutları bağımsız değişkenler olarak belirlenmiştir. Modele göre, kuramsal olarak, çalışanların nepotizme ilişkin boyutlara yönelik algıları arttıkça, örgütsel adalete ilişkin algılarında bir azalma olacağı öngörülmektedir.

Araştırmada, çalışanların örgütsel adalet algılamaları üzerinde, nepotizm ve nepotizm algısına ilişkin boyutların olumsuz bir etkiye sahip olduğu düşüncesinden hareketle aşağıdaki hipotezler geliştirilmiştir:

H1: Nepotizmin boyutlarından 'terfide kayırmacılık' örgütsel adalet algılamasını olumsuz yönde etkilemektedir.

H2: Nepotizmin boyutlarından 'işlem kayırmacılığı' örgütsel adalet algılamasını olumsuz yönde etkilemektedir.

H3: Nepotizmin boyutlarından 'işe alma sürecinde kayırmacılık' örgütsel adalet alg1lamasını olumsuz yönde etkilemektedir.

Ayrıca, çalışanların örgütsel adalet ve nepotizmi algılama düzeylerinin demografik değişkenlere göre farklılık gösterip göstermediği de aşağıdaki hipotezlerle test edilmiştir:

H4: Örgütsel adalet veya nepotizm alg1lamaları yaşa göre farklılık göstermektedir.

H5: Örgütsel adalet veya nepotizm alg1lamaları cinsiyete göre farklılık göstermektedir.

H6: Örgütsel adalet veya nepotizm algilamaları medeni duruma göre farklılık göstermektedir.

H7: Örgütsel adalet veya nepotizm algilamaları eğitim durumuna göre farklılık göstermektedir.

H8: Örgütsel adalet veya nepotizm algılamaları deneyime göre farklılık göstermektedir. 


\subsection{Araştırmanın Yöntemi}

\subsubsection{Anakütlenin Belirlenmesi ve Pilot Araştırma}

Araştırmanın anakütlesi Orta Anadolu Bölgesinde faaliyet gösteren bir aile işletmesinde çalışan 425 kişidir. 425 kişinin tamamina anketler ulaştırılmak suretiyle tam sayım yapılmış, 129 kişiden kullanılabilir anket geri dönüşü sağlanmıştır. Buna göre anketlerin geri dönüş oran1 \%30'dur.

Öncelikle anketlerin yanıtlanması sağlanmadan 25 kişilik bir çalışan kitlesi ile pilot araştırma gerçekleştirilmiş, bu sayede anketi oluşturan ölçeklerin içerik geçerliliğinin de test edilmesine olanak sağlanmıştır. Soruların anlaşılırlığı ve içerik geçerliliği sağlandiktan sonra anket formları yanitlanmak üzere işletmenin yöneticisine teslim edilmiştir.

\subsubsection{Veri Toplama Tekniği ve Aracı}

Araştırmada kullanılan veriler, eş zamanlı olarak uygulanan ve iki farklı ölçekten oluşan anket tekniği ile toplanmıştır. Çalışanların nepotizm algılarının ölçülmesi için; Asunakutlu ve Avcı (2010) tarafından geliştirilen 17 maddelik, örgütsel adalet algılamalarının ölçümü için ise Peelle (2007) tarafından geliştirilen 15 maddelik Kesinlikle Katılmiyorum=1'den Kesinlikle Katıl1yorum=5'e doğru giden beşli likert tipi ölçekler kullanılmıştır.

Asunakutlu ve Avcı tarafından geliştirilen nepotizm ölçeği için yapılan açımlayıcı faktör analizi sonuçlarına göre ölçeğin bir maddesi hariç diğer bütün maddelerin boyutlara dağılımı orijinal ölçekteki boyutlara dağ 1 lım ile paralellik göstermiștir. Ancak faktör analizi sonucu faktör yükleri 0.40 değerinin altında olan 3 madde ölçekten çıkarılmıștır. SPSS 15 ile yapılan açımlayıcı faktör analizi sonuçlarına göre ölçeğin ilk dört maddesi terfide kayırmacilık, 5'ten 9'a kadar olan maddeler işlem kayırmacılığı, 10 'dan 14 'e kadar ola maddeler ișe alma sürecinde kayırmacılık boyutları ile ilgilidir. Özdeğeri 1'den büyük üç boyutun toplam varyansı açıklama oranı $\% 66$ 'dır ve bu oran $\% 60$ 'ın üzerinde olduğu için kabul edilebilir bir değerdir. Ölçeğin örneklem yeterlik katsayısı olan KMO değeri ise 0,87 ile faktör analizi için uygun bir değerdir. Yapılan açımlayıcı faktör analizi sonuçları orijinal ölçeğin üç boyutlu yapısı ile paralellik gösterdiğinden araştırmada kullanılan ölçeğin yap1 geçerliğine sahip olduğu görülmüştür. Asunakutlu ve Avcı tarafindan daha önce yapılan nepotizm ölçeğinin uygulama sonuçlarına göre, ölçeğin güvenirlik katsayısı 0.86 olarak bulunmuşken, bu araştırma için yapılan güvenirlik analizi sonuçlarına göre tüm ölçeğin alpha güvenirlik katsayısı 0.90 olarak hesaplanmiştır.

Anketin ikinci bölümünde çalışanların örgütsel adalet algılamalarını ölçmek amacryla Peelle (2007) tarafından geliştirilen "örgütsel adalet ölçeği" kullanılmıştır. Söz konusu ölçek örgütsel adaleti; dağıtım adaleti, işlem adaleti ve etkileşim adaleti olmak üzere üç alt boyutta incelemektedir. Örgütsel Adalet Ölçeğinin toplam 15 maddesi bulunmaktadır. 15 maddeden oluşan ölçeğin, ilk beş maddesi dağıtım, ikinci beş maddesi işlem ve son beş maddesi ise etkileşim adaletinden oluşmaktadır. Ölçeğin alpha güvenilirlik katsayısı 0.939 olarak hesaplanmıştır.

\subsection{Verilerin Analizi ve Bulgular}

Araştırma verilerinin analizi için öncelikle yanıtlayıcıların demografik özellikleri ile ilgili tanımlayıcı istatistikler ve buna ilişkin yorumlara, sonra ise araştırmanın bağımlı ve bağımsız değişkenleri ile ilgili korelasyon analizi sonuçlarına yer verilmiştir.

Araştırma hipotezlerinin test edilebilmesi için korelasyon, çoklu regresyon analizi ve $t$ testi ile varyans (ANOVA) analizlerine başvurulmuştur.

Araştırmanın örneklemini oluşturan 129 imalat sanayi çalışanına ilişkin demografik bilgiler aşağıdaki Tablo 1'de sunulmuştur.

Tablo 1'deki verilere göre araştırmaya katılanların demografik nitelikleri incelendi- 
Tablo 1

Yanıtlayıcıların Demografik Özellikleri

\begin{tabular}{|c|c|c|c|}
\hline \multicolumn{2}{|c|}{ Demografik Değişkenler } & Frekans & Yüzde \\
\hline \multirow{2}{*}{ Cinsiyet } & Kadın & 32 & 24.8 \\
\hline & Erkek & 97 & 75.2 \\
\hline \multirow{4}{*}{ Yaş } & 25 altı & 36 & 27.9 \\
\hline & $26-35$ & 67 & 51.9 \\
\hline & $36-45$ & 18 & 14 \\
\hline & $46-55$ & 8 & 6.2 \\
\hline \multirow{2}{*}{ Medeni Durum } & Evli & 93 & 72.1 \\
\hline & Bekâr & 36 & 27.9 \\
\hline \multirow{5}{*}{ Kıdem } & 5 yıldan az & 20 & 9.7 \\
\hline & $6-10 \mathrm{yll}$ & 55 & 26.7 \\
\hline & $11-15$ yıl & 60 & 29.1 \\
\hline & $16-20 \mathrm{yll}$ & 37 & 18 \\
\hline & 21 yıldan fazla & 34 & 16.5 \\
\hline \multirow{4}{*}{ Eğitim Düzeyi } & İlköğretim & 47 & 36.4 \\
\hline & Lise & 74 & 57.4 \\
\hline & MYO & 6 & 4.7 \\
\hline & Fakülte & 2 & 1.6 \\
\hline
\end{tabular}

ğinde; yanıtlayıcılardan yaklaşık dörtte üçünün erkek, büyük çoğunluğunun evli, yine üçte ikisinin 26-35 yaş aralığında, kıdem olarak yarıdan fazlasının altı ila15 yıl aralığından kıdeme sahip oldukları ve eğitim durumu bakımindan ise nerede ise tamam1nın ilköğretim ve lise mezunlarından oluştuğu görülmektedir. Yani ilgili işletme emek yoğun sektörde faaliyet gösteren ve mavi yakalı, görece niteliksiz işgücünden oluşan, bir profil sergilemektedir.

Araştırmada, nepotizm ile örgütsel adalet arasındaki ilişkiyi belirlemek amacıyla analizlere başlanmış ve bunun için değişkenler arasındaki Pearson korelasyon katsa-

Tablo 2

Nepotizm İle Örgütsel Adalet İlişkisi

\begin{tabular}{|l|l|l|}
\hline Değişkenler & $\mathbf{N}$ & $\begin{array}{l}\text { Pearson } \\
\text { Korelasyon }\end{array}$ \\
\hline Nepotizm & 129 & $\begin{array}{l}-0.204^{*} \\
\text { Sig. (2-tailed) }\end{array}$ \\
\hline Örgütsel Adalet & 129 &
\end{tabular}

yısı hesaplanarak sonuç Tablo 2'de sunulmuştur.

Tablo 2'deki - 0.204 değeri çalışanların nepotizm algılamaları ile örgütsel adalet alg1lamaları arasında ters yönlü fakat düşük düzeyde bir ilişki olduğunu göstermektedir. Bu sonuç, her ne kadar iki değişken arasında bir neden sonuç ilişkisinin varlığını göstermese de çalışanların nepotizm algılamaları arttıkça, örgütsel adalet algılamalarında bir azalış olduğuna işaret etmektedir. Bu istatistiksel sonuç ilgili kuramdan yola çıkıldığında beklenen bir sonuçtur. Bu sonuçlar; Araslı ve diğg., (2006), Keleş ve diğ., (2011), Barnett ve Kellermanns'ın (2006) ön görüleri ile örtüşmekte, Büte ve Tekarslan (2010) tarafından yapılan araştırma bulguları ile paralellik göstermektedir.

Bu bölümde örgütsel adalet ile nepotizm algısının boyutlarına ilişkin değişkenler arasındaki bir dizi tanımlayıcı istatistikler ile değişkenler arası korelasyon sonuçlarına yer verilmiştir. İlgili sonuçlar Tablo 3'deki gibi özetlenmiştir. 


\section{Tablo 3}

Araştırma Değişkenlerine İlişkin Tanımlayıcı İstatistikler ve Korelasyonlar

\begin{tabular}{|l|c|c|c|c|c|c|}
\hline \multicolumn{1}{|c|}{ Değişkenler } & $\bar{X}$ & $\boldsymbol{\alpha}$ & $\mathbf{1}$ & $\mathbf{2}$ & $\mathbf{3}$ & $\mathbf{4}$ \\
\hline 1. Örgütsel Adalet & 2.98 & .88 & - & & & \\
\hline 2. Nepotizm(Terfide Kayırmacılık) & 3.66 & .81 & $-.228^{*}$ & - & & \\
\hline 3. Nepotizm (İşlem Kayırmacılığı) & 3.04 & .77 & -.105 & 000 & - & \\
\hline 4.Nepotizm (İşe Alma Sürecinde Kayırmacılık) & 3.47 & .79 & $-.209 *$ & 000 & 000 & - \\
\hline
\end{tabular}

$\mathrm{p}<.05$

Tablo 3'deki örgütsel adalet algisının ortalama değeri 2.98 ile "ne katılıyorum ne katılmıyorum" seçeneğine yakın bir değerdir. Buna göre çalışanlar, işletme uygulamaları konusunda yeterli sayılabilecek bir adalet algilamasına sahip değildirler. Nepotizm algisı ile ilgili boyutların ortalamalarına bakıldı ğında genel ortalamanın 3.39 ile ortalama değerin biraz üzerinde ne katılıyorum ne katılmıyorum seçeneğine daha yakın bir noktada toplandığı ve buradan çalışanların nepotizm algılamalarının adalet algılamaları ortalamasına göre biraz daha yüksek bir değer aldığı görülmektedir. Örgütsel adalet ve nepotizme ilişkin boyutların alpha güvenirlik katsayıları bakımından tatmin edici değer olan 0.70'e yakın ve üzerinde değerler aldıkları bulgusuna ulaşılmıştır. Değişkenler arası korelasyonlara bakıldığında da örgütsel adalet ile nepotizmin boyutlarından terfide kayırmacilık (p. -0.228) boyutunun en yüksek ters yönlü korelasyon ilişkisine sahip olduğu görülmektedir. Yine çalışanların al- gıladıkları işe alma sürecinde kayırmacılık uygulamaları ile örgütsel adalet algısı arasinda (p. -0.209) ile ters yönlü ve düşük bir korelasyon ilişkisi tespit edilmiştir. Bu sonuçlar, terfide kayırmacılık ve işe alma sürecinde kayırmacılık algısı arttıkça, örgütsel adalete ilişkin algılamaların azaldığı şeklinde yorumlanabilir.

Yapılan çoklu regresyon analizi ile araştırma modeli ve modele ilişkin geliştirilmiş olan hipotezler test edilmiş ve elde edilen bulgular yorumlanmaya çalışılmıştır. Tablo 4'teki tanımlayıcılık katsayısı (R2), doğrusal modelin uyum iyiliğinin en yaygın ölçüm biçimidir. Söz konusu katsayı, bağımlı değişkendeki değişimin ne kadarının bağımsız değişkenler tarafından açıklandığını göstermektedir. Bu durum regresyon modelinin açıklayıcılık gücünün iyi bir ifadesidir. Buradan hareketle, örgütsel adalet algısına ilişkin değişimin 0.125 'i araştırma modelinde yer alan ve nepotizm algisina ait boyutlardan olan; terfide, işlemde ve işe alma süre-

\section{Tablo 4}

Regresyon Modelinin Özeti

\begin{tabular}{|l|l|l|c|c|c|}
\hline Model & $\mathbf{R}$ & $\mathbf{R}^{2}$ & Düz. $\mathbf{R}^{2}$ & Tah.Stnd Hatası & DW \\
\hline 1 & $.395(a)$ & .125 & .104 & .34678 & 1.754 \\
\hline
\end{tabular}

a Tahmin Değişkeni: Terfide Kayırmacılık, İşlem Kayırmacılı̆̆ı, İşe Alma Sürecinde Kayırmacılık

b Bağımlı Değişken: Örgütsel Adalet 
Tablo 5

Varyans Analizi ANOVA(b) Sonuçları

\begin{tabular}{|c|c|c|c|c|c|}
\hline Model & Kar.Top & Df & Ort. Karesi & F & Sig. \\
\hline 1 Regression & 5.353 & 2 & 1.424 & 11.439 & $\mathbf{0 . 0 0 0 a}$ \\
\hline Residual & 25.543 & 167 & .142 & & \\
\hline Total & 27.342 & 177 & \multicolumn{3}{|l}{} \\
\hline
\end{tabular}

a Tahmin Değişkeni: Terfide Kayırmacılık, İşlem Kayırmacılı̆̆ı, İşe Alma Sürecinde Kayırmacılık

b Bağımlı Değişken: Örgütsel Adalet

cinde kayırmacılık bağımsız değişkenleri tarafından açıklanmaktadır. Bir başka deyişle örgütsel adalet algısının ortaya çıkmasında, çok sayıda etkileyici faktörden biri olan nepotizme ilişkin boyutların sadece 0,125 gibi oldukça düşük düzeyde bir istatistiksel etkiye sahip olduğundan bahsedilebilir. Araştırmada kullanılan Durbin Watson (DW) testi, modeldeki değişkenler arasında otokorelasyon olup olmadı ğını ortaya koyan bir testtir. Otokorelasyon hata terimlerinin birbirleriyle ilişkili olma durumudur. Söz konusu test değerinin 1.5 ile 2.5 aralığında olması istenmektedir. Tablo 4 'te görüleceği gibi analiz sonucuna göre Durbin Watson değeri 1.754 ile arzulanan aralıkta yer almaktadır.

Ayrıca, Tablo 5'teki varyans analizi sonuçlarına göre F değeri 11.439'nın 0.000 anlamlılık düzeyinde geçerli olması modelin bütün olarak geçerli olduğunu ve söz ko- nusu işletmedeki çalışanların, örgütsel adalet algisının 0.125 'inin modelde yer alan bağımsız değişkenler tarafından açıkladığını göstermektedir. 0.125 değeri, örgütsel adalet algısının olumlu veya olumsuz yönde oluşumuna neden olabilecek bireysel ve örgütsel model dışı çok farklı değişkenlerin de olabileceği göz önünde bulundurulduğunda makul bir sonuç olarak karşılanabilir.

Nepotizm algısına ilişkin; terfide kayırmacılık, işlem kayırmacılığı ve işe alma sürecinde kayırmacılık boyutlarından oluşan bağımsız değişkenlerin, bağımlı değişken olan örgütsel adalet algısı üzerindeki etkisini görebilmek için standart çoklu regresyon analizi sonuçlarının yer aldığı Tablo 6'ya bakıldığında, terfide kayırmacılık (sig. .000) ve işe alma sürecinde kayırmacılık (sig..001) boyutlarının örgütsel adalet algısı üzerinde anlamlı bir etkiye sahip olduğu sonucuna varılmıştır. İşlem kayırmacılığ

\section{Tablo 6}

Çoklu Regresyon Analizi Sonuçları

\begin{tabular}{|c|c|c|c|c|c|c|}
\hline \multirow[b]{2}{*}{ Model } & \multicolumn{2}{|c|}{$\begin{array}{c}\text { Standardize Edilmemiş } \\
\text { Katsayılar }\end{array}$} & \multirow[b]{2}{*}{ Beta } & \multirow[b]{2}{*}{ Sig. } & \multicolumn{2}{|c|}{ Doğrusal Bağlantı } \\
\hline & $B$ & Stn. Hata & & & Tolerance & VIF \\
\hline 1 (Sabit) & 3.66 & .014 & & .000 & & \\
\hline Terfide Kayırmacılık & -.126 & .014 & -.228 & .000 & 1.00 & 1.00 \\
\hline İşlem Kayırmacılığı & -.052 & .014 & -.105 & .069 & 1.00 & 1.00 \\
\hline $\begin{array}{l}\text { İşe Alma Sürecinde } \\
\text { Kayırmacılık }\end{array}$ & -.092 & .014 & -.209 & .001 & 1.00 & 1.00 \\
\hline
\end{tabular}

Bağımlı Değişken: Örgütsel Adalet 
Tablo 7

Çalışanların Yaş Gruplarına Göre Nepotizm ve Örgütsel Adalet Algılamaları Arasındaki Farkı Gösteren ANOVA Testi Sonuçları

\begin{tabular}{|l|c|c|c|l|l|}
\hline & N & Df & Mean squr. & F & Sig. \\
\hline Nepotizm & 129 & 3 & .380 & .494 & .687 \\
\hline Örgütsel Adalet & 129 & 3 & .393 & .423 & .736 \\
\hline
\end{tabular}

ise örgütsel adalet algısı üzerinde herhangi bir etkiye sahip olmadığı tespit edilmiştir.

Bu sonuçlara göre "Nepotizmin boyutlarından 'terfide kayırmacılık' örgütsel adalet algılamasını olumsuz yönde etkilemektedir." şeklindeki H1 ve "Nepotizmin boyutlarından 'İşe alma sürecinde kayırmacılık' örgütsel adalet algılamasını olumsuz yönde etkilemektedir" şeklindeki H3 hipotezleri desteklenmektedir. Ancak, "Nepotizmin boyutlarından 'işlem kayırmacılığı' örgütsel adalet algılamasını olumsuz yönde etkilemektedir" şeklindeki H2 hipotezi ise reddedilmektedir. Terfide kayırmacılık boyutu ile ilgili elde edilen bu sonuç, Büte (2011) tarafından nepotizmin iş stresi, iş tatmini, olumsuz söz söyleme gibi bir takım örgütsel çıktılarla ilgili araştırmasının bulgularından olan terfide kayırmacılığın örgütsel adalet algısı üzerindeki olumsuz etkisi ile bağdaşır niteliktedir (Büte, 2011: 190).

Regresyon analizlerinde, analize dâhil edilen bağımsız değişkenler arasında çoklu doğrusal bağlantının olmaması gerekmektedir. Değişkenler arasında çoklu doğrusal bağlantının olup olmadığını ifade edebilmek için doğrusal bağlantı (Collinearity) sütunundaki Tolerans ve VIF değerlerine bakılmaktadır. İlgili değerlerden tolerans değerinin düşük, VIF değerinin yüksek olması halinde değişkenler arasında çoklu bağlantı olduğu ve modelin parametrelerini tahmin etmenin mümkün olmadığ1 sonucuna varılır (Akgül ve Çevik, 2003: 341). Gujarati söz konusu değerin "parmak hesabı" ile 10'dan büyük olması, Tarı ise ilgili değerin beşten büyük olması halinde çoklu doğrusal bağlantının olacağına işaret etmektedirler (Gujarati; 1999: 338-339; Tar1, 2008: 167). Buna göre Tablo 6'daki araştırma bulgularına bakıldığında, örgütsel bağl1lığın her üç boyutuna ilişkin algılamalar ile ilgili değişkenlerin tolerans değerlerinin çok düşük ve VIF değerlerinin ise çok yüksek olmadığı ve buna göre bağımsız değişkenler arasında her hangi bir doğrusal bağlantının bulunmadiğ 1 tespit edilmiştir.

Çalışanların demografik özellikleri bak1mindan nepotizm veya örgütsel adalet alg1 düzeyleri arasında bir farklılık olup olmadığ i ile ilgili olarak ise t-testi ve varyans analizi (ANOVA) sonuçları dikkate alınmıştır.

Çalışanların nepotizm ve örgütsel adalet alg1sı düzeylerinin yaş gruplarına göre farklılık gösterip göstermediğine bakılmıştır. Tablo 7'deki ANOVA testi sonuçlarına göre nepotizm algısı için sig. 0.687 ve örgütsel adalet algısı için sig. 0.736 bulunmuş ve çal1şanlar arasında yaş grupları itibari ile her hangi bir farklılık olmadığ 1 sonucuna ulaşılmıştır. Bu sonuca göre "Örgütsel adalet veya nepotizm algılamaları yaşa göre farklılık göstermektedir" şeklindeki H4 hipotezi reddedilmektedir.

Demografik değişkenlerden cinsiyete göre, çalışanların nepotizm ve örgütsel adalet alg1 düzeyleri bakımından farklılık olup olmadığına $\mathrm{t}$ testi ile bakılmıştır. Tablo 8'deki değerlere bakıldığında gerek nepotizm (sig. 0.404) ve gerekse örgütsel adalet (sig. 0.419) algısının cinsiyet değişkeninden etkilenmediği sonucuna ulaşılmıştır. Elde edilen bu sonuçlar "Örgütsel adalet veya nepotizm algılamaları cinsiyete göre farklılık göstermektedir." şeklindeki H5 hipotezinin reddedilmesine neden olmaktadır. 
Tablo 8

Çalışanların Cinsiyete Göre Nepotizm ve Örgütsel Adalet Algı Düzeyleri Arasındaki Farkı Gösteren T Testi Sonuçları

\begin{tabular}{|l|l|l|l|l|l|}
\hline & $\mathbf{N}$ & $\bar{X}$ & $\mathbf{t}$ & $\mathbf{d f}$ & Sig. (2-tailed) \\
\hline Nepotizm & \multirow{3}{*}{$\begin{array}{l}\text { Kadın=32 } \\
\text { Ërkek = 97 }\end{array}$} & $\begin{array}{l}\text { Kadın: } 2.86 \\
\text { Orgütsel }\end{array}$ & -.836 & 127 & .404 \\
\cline { 3 - 6 } & & $\begin{array}{l}\text { Kadın: } 3.00 \\
\text { Erkek: } 3.28\end{array}$ & -.836 & 127 & .419 \\
\hline
\end{tabular}

Tablo 9

Çalışanların Medeni Duruma Göre Nepotizm ve Örgütsel Adalet Alg1 Düzeyleri Arasındaki Farkı Gösteren T Testi Sonuçları

\begin{tabular}{|l|l|l|l|l|l|}
\hline & $\mathbf{N}$ & $\bar{X}$ & $\mathbf{t}$ & $\mathbf{d f}$ & Sig. (2-tailed) \\
\hline \multirow{2}{*}{ Nepotizm } & \multirow{3}{*}{$\begin{array}{l}\text { Evli= 93 } \\
\text { Örgütsel Adalet }\end{array}$} & $\begin{array}{l}\text { Evli: } 2.84 \\
\text { Bekar = 36 }\end{array}$ & -1.093 & 127 & .276 \\
\cline { 3 - 6 } & & $\begin{array}{l}\text { Evli: } 3.09 \\
\text { Bekar: } 3.32\end{array}$ & -1.122 & 127 & .223 \\
\hline
\end{tabular}

\section{Tablo 10}

Çalışanların Eğitim Düzeylerine Göre Nepotizm ve Örgütsel Adalet Algılamaları Arasındaki Farkı Gösteren Varyans Analizi (ANOVA) Sonuçları

\begin{tabular}{|c|c|c|c|c|c|}
\hline & $\mathbf{N}$ & df & Mean square & $\mathbf{F}$ & Sig. \\
\hline Nepotizm & \multirow[t]{2}{*}{129} & 3 & .395 & 1.185 & .674 \\
\hline Örgütsel Adalet & & 3 & .279 & .100 & .960 \\
\hline
\end{tabular}

Demografik değişkenlerden medeni duruma göre nepotizm veya örgütsel adalet algisı arasında farklılık olup olmadığına $t$ testi ile bakılmıştır. Tablo 9'daki anlamlılık değerlerine bakıldığında nepotizm (p. 0.276) ve örgütsel adalet algisında medeni durum itibari ile her hangi bir farklılık olmadığı sonucuna ulaşılmıştır. Buna göre, "Örgütsel adalet veya nepotizm algılamaları medeni duruma göre farklılık göstermektedir.." şeklindeki H6 hipotezi desteklenmemektedir.

Araştırmada çalışanların eğitim seviyele- rine göre, nepotizm ve örgütsel adalet alg1lamalarında bir farklılık olup olmadığına bakılmıştır. Tablo 10'daki varyans analizi sonuçlarına göre toplam dört farklı eğitim düzeyi arasinda nepotizm (p. 0.674) ve örgütsel adalet (p. 0.960) bakımından anlamlı bir farklılık olmadığı sonucuna varılmıştır. Bu sonuçlara göre, "Örgütsel adalet veya nepotizm algılamaları eğitim durumuna göre farklılık göstermektedir" biçiminde geliştirilmiş olan $\mathrm{H} 7$ hipotezi reddedilmektedir.

Araştırmada çalışanların iş deneyimle- 


\section{Tablo 11}

Çalışanların İş Deneyimlerine Göre Nepotizm ve Örgütsel Adalet Algılamaları Arasındaki Farkı Gösteren Varyans Analizi (ANOVA) Sonuçları

\begin{tabular}{|l|c|c|c|c|lc|}
\hline & $\mathbf{N}$ & df & Mean square & F & \multicolumn{1}{c|}{ Sig. } \\
\hline Nepotizm & 129 & 3 & .395 & 1.185 & .674 & \\
\cline { 4 - 7 } Örgütsel Adalet & & 3 & .279 & .100 & .960 & \\
\cline { 3 - 6 }
\end{tabular}

rine göre, nepotizm ve örgütsel adalet alg1lamalarında bir farklılık olup olmadığına da bakılmıştır. Tablo 11'deki varyans analizi sonuçlarına göre toplam dört farklı deneyim veya kıdem düzeyi itibari ile nepotizm (p. 0.932) ve örgütsel adalet (p. 0.451) algısında anlamlı bir farklılık olmadığı sonucuna varılmıştır. Bu sonuçlara göre, "Örgütsel adalet veya nepotizm algılamaları deneyime göre farklılık göstermektedir." şeklinde geliştirilmiş olan $\mathrm{H} 8$ hipotezi reddedilmektedir.

Buna göre araştırma için geliştirilen hi- potezler ve hipotez testi sonuçları Tablo 12 'deki gibi özetlenebilir.

Elde edilen sonuçlara göre çalışanların nepotizm ve örgütsel adalet algılamaları arasinda negatif yönlü fakat düşük düzeyde bir ilişki olduğu tespit edilmiştir. Çalışanlar, kayırmacılığa ilişkin bir algıya sahip olduklarinda bu durum organizasyonda bir haksızlık veya adaletsizlik olduğuna ilişkin bir algılama oluşturmaktadır ki bu sonuç aslında beklenen bir sonuçtur. Araştırma ile ulaşılan bir başka bulgu, araştırmaya katılan

\section{Tablo 12}

Hipotez Testi Sonuçları

\begin{tabular}{|l|l|c|}
\hline Hipotezler & \multicolumn{1}{|c|}{ Test } & Sonuç \\
\hline $\begin{array}{l}\mathrm{H}_{1}: \text { Nepotizmin boyutlarından 'terfide kayırmacılık' örgütsel } \\
\text { adalet algılamasını olumsuz yönde etkilemektedir. }\end{array}$ & $\begin{array}{l}\text { Çoklu Regresyon Analizi (sig. } \\
0.000 \text { ) }\end{array}$ & Kabul \\
\hline $\begin{array}{l}\mathrm{H}_{2} \text { : Nepotizmin boyutlarından 'işlem kayırmacılı̆̆ı' örgütsel adalet } \\
\text { algılamasını olumsuz yönde etkilemektedir. }\end{array}$ & $\begin{array}{l}\text { Çoklu Regresyon Analizi (sig. } \\
0.069)\end{array}$ & Red \\
\hline $\begin{array}{l}\mathrm{H}_{3}: \text { Nepotizmin boyutlarından 'işe alma sürecinde kayırmacılık' } \\
\text { örgütsel adalet algılamasını olumsuz yönde etkilemektedir.. }\end{array}$ & $\begin{array}{l}\text { Çoklu Regresyon Analizi (sig. } \\
0.001)\end{array}$ & Kabul \\
\hline $\begin{array}{l}\mathrm{H}_{4}: \text { Örgütsel adalet veya nepotizm algılamaları yaşa göre farklılık } \\
\text { göstermektedir. }\end{array}$ & ANOVA (sig.0.736 ve 0.687 & Red \\
\hline $\begin{array}{l}\mathrm{H}_{5}: \text { Örgütsel adalet veya nepotizm algılamaları cinsiyete göre } \\
\text { farklılık göstermektedir. }\end{array}$ & T Testi (p.0.419 ve 0.404) & Red \\
\hline $\begin{array}{l}\mathrm{H}_{6}: \text { Örgütsel adalet veya nepotizm algılamaları medeni duruma } \\
\text { göre farklılık göstermektedir. }\end{array}$ & T Testi (p.0.223ve 0.276) & Red \\
\hline $\begin{array}{l}\mathrm{H}_{7}: \text { Örgütsel adalet veya nepotizm algılamaları eğitim durumuna } \\
\text { göre farklılık göstermektedir. }\end{array}$ & ANOVA (sig.0.960 ve 0.674) & Red \\
\hline $\begin{array}{l}\mathrm{H}_{8}: \text { Örgütsel adalet veya nepotizm algılamaları deneyime göre } \\
\text { farklılık göstermektedir. }\end{array}$ & ANOVA (sig.0.932 ve 0.451) & Red \\
\hline
\end{tabular}


çalışanların nepotizm algılamalarına ilişkin ortalamalarının, örgütsel adalete ilişkin ortalamalarından biraz daha yüksek olduğu yönündedir.

Araştırmada nepotizmin boyutlarından olan; terfide kayırmacılık, işlem kayırmac1lığ1 ve işe alım sürecinde kayırmacılık boyutlarının örgütsel adalet algısı üzerindeki etkisine çoklu regresyon analizi ile bakılmıştır. Analiz sonuçlarına göre örgütsel adalet alg1sı üzerinde en güçlü etkiye terfide kayırmacılık ve işe alım sürecinde kayırmacılık boyutlarının sahip olduğu görülmüştür. Terfi ve işe alım süreci, çalışanların örgütteki faaliyet ve uygulamalar konusunda, eşitlikçi ve adil olunup olunmadığını en sık takip ettikleri İK uygulamalarındandır. Bu nedenle söz konusu işletmedeki çalışanlar, ilgili süreçlerle alakalı nepotist algılamalar sonucu örgütteki uygulamaların adaletli olmadığ konusunda bir kanı oluşturmuşlardır. Örgütsel adalet algısında aşınmaya kadar giden bu nepotist uygulamalar işletme yöneticilerinin, aileden olanlara karşı daha fazla güven duymaları, onların işletmeye bağlılıklarının diğger çalışanlardan daha fazla olacağına inanmaları ve yine bu çalışanların örgütsel özdeşleşme düzeyinin daha yüksek olacağına olan inançları ile açıklanabilir.

Demografik değişkenlere göre çalışanların nepotizm ve örgütsel adalet algılama düzeyleri yönünden bir fark gösterip göstermediği ile ilgili hipotez testi sonuçlarına göre çalışanların gerek nepotizm gerekse örgütsel adalet algılamaları bakımından her hangi bir farklılık göstermedikleri tespit edilmiştir.

\section{Sonuç ve Öneriler}

$\mathrm{Bu}$ araştırmada, çalışanların nepotizm ve nepotizm algılamalarına ilişkin boyutların örgütsel adalet algısı üzerindeki etkisi incelenmiştir. Araştırma sonuçlarına göre nepotizm ile örgütsel adalet algılamaları arasında ters yönlü ve düşük düzeyde bir ilişkinin olduğu ortaya konulmuştur. Öte yandan nepotizmin boyutlarindan olan terfide kayırmacılık ile işe alma sürecinde kayırma- c1lığın örgütsel adalet algılaması üzerinde de ters yönlü ve zayıf bir ilişkiye sahip olduğu sonucuna ulaşılmıştır.

Araştırma sonuçlarına göre nepotizmin (kayırmacılığın) profesyonel bir İKY anlayışı ile bağdaşmayacağı, örgüt üyeleri arasında sadece aileden olanlara yarar sağlayabileceğinden söz edilebilir. Nepotizm özellikle çalışanlar arasında algılanan adalet boyutunu etkilemektedir. İsletmeler ancak her çalışanın ortaya koyacağı katkı ile başarıya ulaşabilir. Kayırmacılık ise, başarıya giden bu takım ruhuna zarar vermektedir. Ortaya çıkan adaletsiz iklim örgütsel başarıya önemli zararlar verecektir.

Örgütler ancak tüm çalışanların ortak katkıları ve kurumsallaşmasını tamamlamış yapı içinde amaçlarına ulaşabilir. Bunun aksine nepotizm veya kayırmacılığın zemin bulduğu örgütlerde ise başarısızlık ve hem bireysel hem de örgütsel performans düşüklüğü ortaya çıkabilecektir. Ayrıca nepotizm algısının yüksek olduğu örgütlerde, çalışanlar pozisyonlarını korumak veya yükseltmek için daha fazla gayret göstermek yerine, fırsatını bulduğu anda kayırma görebileceği herhangi bir aile bireyi ile yakın ilişkide bulunmayı tercih edebilecektir.

Nepotizmin olumsuz etkilerinden kaçınmak konusunda aile işletmelerine aşağıda s1ralanan bazı önerilerde bulunulabilir: Aile işletmelerinin yöneticileri kayırmacılık yapmaktan kaçınmalı, çalışanların adalet algılamalarını zedelemeyen bir İKY sistemi geliştirmeli ve açık, hesap verebilir ve şeffaf bir yöneti(şi)m anlayışını benimsemelidir. Özellikle terfi, işe alım süreci ve işlem kayırmacılığına karşı gerekirse profesyonel danışmanlık şirketlerinden yardım alma yoluna gidilmelidir. Aile üyesi olan yöneticiler; profesyonelce düşünerek, genellikle duygularıyla değil, mantığı ile hareket etmeli, özellikle İK ile ilgili konularda objektif davranmaya özen göstermelidir. Sonuç olarak, nepotizmin özellikle aileden olanlar üzerinde belirlenmiş olumlu sonuçları olmasına rağmen aile üyesi olmayan işgörenler üzerinde olumsuz etkileri çok daha 
fazladır. Bu nedenle aile işletmelerinde uzun süre çalışan, işi ve işletme içi dinamikleri iyi bilen, deneyimli çalışanların, adaletsizlik algılamalarının önüne geçilmesi, kayırmac1lığa dayalı terfi ve İK uygulamalarına yönelik tedbirler alınması ve zaman kaybedilmeden kurumsallaşmayı sağlayıcı adımlar atılması büyük önem taşımaktadır. Bu araştırma ile Orta Anadolu Bölgesindeki bir aile işletmesinde çalışanların nepotizm ve örgütsel adalet algılamaları arasındaki ilişki sinırlı bir örneklem grubu üzerinde yapılan çalışma ile ortaya konulmuştur. Bu nedenle ulaşılan sonuçların temkinli değerlendirilmesi yerinde olacaktır. Bundan sonra yap1lacak çalışmalarda nepotizmin; performans, personel devir oranı, örgütsel bağlllık, is tatmini ve işe devamsızlık gibi diğer örgütsel değişkenlerle ilişkisini ortaya koyacak çalışmalar yapılabilir. Kavramın belirli boyutları bağlamında örgütsel adalet algılamaları ile ilişkisi incelenebilir. Yine söz konusu boyutların örgütsel adaletin boyutlarından dağ1tım, işlem ve etkileşim adaleti üzerindeki etkisine de ayrı ayrı bakılabilir. Ayrıca konu, kapsayıcı genellemelere varabilmek ve daha güçlü sonuçlara ulaşabilmek bakımından, farklı metodolojik yaklaşımlarla ele alınabilir ve böylece ilgili alan yazının zenginlik kazanmasına da katkıda bulunulabilir.

\section{KAYNAKÇA}

Abdalla, H.F., Maghrabi, A.S., Raggad, B.G. (1995), Assessing the Perceptions of Human Resource Managers Toward Nepotism A Cross-Cultural Study, International Journal of Manpower, 19,8, pp.554-570.

Akgül, Aziz ve Çevik, Osman (2003) İstatistiksel Analiz Teknikleri, Ankara: Emek Ofset.

Aközer, Mehmet (2003) Kamuoyu Gözüyle Kamu da Yolsuzluk, Görüş Dergisi, Aralık, ss.14-22.

Altıntaş, Füsun (2006), Bireysel Değerlerin Örgütsel Adalet ve Sonuçları İlişkisinde Yönlendirici Etkisi: Akademik Personel Üzerinde Bir Analiz, İşletme Fakültesi Dergisi, 7(2), ss.19-40.

Araslı, Hüseyin, Bavik, Ali, Ekiz, Erdoğan H. (2006), The Effects of Nepotism on Human Resource Management The Case of Three, Four and Five Star Hotels in Northern Cyprus, International Journal of Sociology and Social Policy Vol. 26 No. 7/8, pp. 295-308.

Asunakutlu, Tuncer ve Avc1 Umut (2010), Aile İşletmelerinde Nepotizm Algısı ve İş Tatmini İlişkisi Üzerine Bir Araştırma, Süleyman Demirel Üniversitesi, İktisadi ve İdari Bilimler Fakültesi Dergisi, 15/2, ss.93-109.

Barling, Julian ve Phillips, Michelle (1993) Interactional, Formal and Distributive Justice in The Workplace: An Exploratory Study. Journal of Psychology, Vol:127, No:6, pp. 649-656.

Bayhan, Vehbi (2002) Demokrasi ve Sivil Toplum Örgütlerinin Engelleri: Patronaj ve Nepotizm, Cumhuriyet Üniversitesi İ̈BF Dergisi, Cilt 26, No: 1, ss.1-13 
Büte, Mustafa. (2011), Nepotizmin İş Stresi, İş Tatmini, Olumsuz Söz Söyleme ve İşten Ayrılma Niyeti Üzerine Etkileri, Ç.Ü. Sosyal Bilimler Enstitüsü Dergisi, Cilt 20, Sayı 1, ss.177-194.

Büte, Mustafa ve Tekarslan Erdal (2010), Nepotizmin Çalışanlar Üzerine Etkileri: Aile İşletmelerine Yönelik Bir Saha Araştırması, Ekonomik ve Sosyal Araştırmalar Dergisi, Bahar 2010, Cilt:6, Y11:6, Sayı:1, ss.1-21

Carrell, Michael R. ve Dittrich, John E. (1978) Equity Theory: The Recent Literature, Methodological Considerations, and New Directions, Academy of Management Review, Vol. 3, No.2, ss. 202-210.

Colquitt, Jason, A., Conlon, Donald E., Wesson, Michael, J., Porter, Christopher O., $\mathrm{Ng}$, Yee, K.. (2001) Justice at the millennium: A meta-analytic review of 25 years of organizational justice research. Journal of Applied Psychology, 86(3), ss. $425-445$.

Erdoğmuş, Nihat (2004) Aile İşletmeleri: İkinci Kuşağın Yetiştirilmesi, İstanbul: İgiad Yayınları.

Ford, Robert ve McLaughin, Frank (1985), Nepotism, Personnel Journal, 64 (9), ss.57-60.

Garih, Üzeyir (2000). Yönetim İlkeleri, İstanbul: Hayat Yayınları.

Greenberg, Jerald (1990) Organizational Justice: Yesterday, Today and Tomorrow, Journal of Management, Vol: 16, No: 2, ss.399-432.

Gujarati, Damodar N. (1999) Temel Ekonometri, 1. Baskı, Çev. Ümit Şenesen ve Gülay G. Şenesen, İstanbul: Literatür Yayincilik.
Günel, Rıdvan (2005) Aile İşletmelerinde Yönetimin Bir Sonraki Kuşağa Devrinde Karşılaşılan Sorunların Tespitine ve Bu Sorunların Çözümüne İlişkin Bir Araştırma. Çukurova Üniversitesi Sosyal Bilimler Enstitüsü, Yayımlanmamış Yüksek Lisans Tezi. Adana.

Irak, Uysal, D. (2004) Örgütsel Adalet: Ortaya Çıkışı, Kuramsal Yaklaşımlar ve Bugünkü Durumu. Türk Psikoloji Yazıları, Cilt:7, No: 13, ss.25-43.

İçerli, Leyla (2010), “Örgütsel Adalet: Kuramsal Bir Yaklaşım", Girişimcilik ve Kalkınma Dergisi, 5:1, ss. 67-92.

İyiişleroğlu, Salih C. (2006) Aile Şirketleri: Adana ve Çevresinde Faaliyet Gösteren Aile Şirketlerinde Nepotizm Uygulamasının Tespitine Yönelik Bir Araştırma, Çukurova Üniversitesi Sosyal Bilimler Enstitüsü, Yayımlanmamış Yüksek Lisans Tezi, Adana.

Joffe, Alexander H. (2004), Nepotism for All Times, Society, September/October, ss. 74-79.

Karakaş, Mehmet ve Çak, Murat (2007) Yolsuzlukla Mücadelede Uluslararası Kuruluşların Rolü, Maliye Dergisi, Say1: 153, ss.74-101 .

Karpuzoğlu, Ebru (2001) Büyüyen ve Gelişen Aile Şirketlerinde Kurumsallaşma, İstanbul: Hayat Yayınları.

Keleş, Hatice N., Özkan, Tuğba K., Bezirci, Muhammet (2011), A Study on The Effects of Nepotism, Favoritism, and Cronyism on Organizational Trust in the Auditing Process in Family Businessess in Turkey, International Business \& Economics Research Journal, September, Volume 10, Number 9, ss. 9-16. 
Kurgun, Avşar, Güripek, Ediz, Aktaş, Erdem (2010) Nepotizmin Çalışanların Örgütsel Adalet Alg1lamaları Üzerine Etkisi, 18. Ulusal Yönetim ve Organizasyon Kongresi, Çukurova Üniversitesi, Adana.

McDowall Almuth, ve Fletcher, C, (2004) Employee Development: an Organizational Justice Perspective, Personnel Review, Cilt. 33, Say1: 1, ss. 8 - 29

Merriam-Webster Online Dictionary, available at: www.m-w.com/cgi- in/dictionary?bbook=Dictionary\&va $=$ Trust $\& \mathrm{x}=$ 12\&y=3 (Erişim tarihi 17 April 2011)

Nabatchi, Tina, Bingham, Lisa, B., Good, David H. (2007) Organizational Justice and Workplace Mediation: A Six Factor Model. International Journal of Conflict Management, 18, (2), ss.148-176.

Olson Patricia. D.,Virginia Zuiker, S, Danes, Sharon M., Stafford Kathryn, Heck, Ramona K.Z., Duncan Karen A., (2003) The Impact Of The Family and The Business On Family Business Sustainability, Journal of Business Venturing, Cilt 18, Say1 5, ss. 639-666.

Özer, Gökhan ve Günlük, Mehmet, (2010) Örgütsel Adaletin Muhasebecilerin İş Memnuniyeti ve İșten Ayrılma eğilimine Etkisi, Gaziantep Üniversitesi Sosyal Bilimler Dergisi, 9(2), ss. 459-485.

Özkaya, Onay M ve Sengül, Muter C. (2006) Aile Şirketlerinde Kurumsallaşma ve İkinci Kuşağın Kurumsallaşma Konusuna Bakış Açısı", Marmara Üniversitesi İ̈BF Dergisi, Cilt:28, Sayı:1, ss. 257-272.

Özler, Hayrettin, Özler Ergun Derya ve Gümüştekin, Gülten Eren, (2007) Aile İşletmelerinde Nepotizmin Gelişim Evreleri ve Kurumsallaşma, Selçuk Üniversitesi Sosyal Bilimler Enstitüsü Dergisi, Cilt: 17, ss. 437-450.
Özsemerci, Kemal, (2003) Türk Kamu Yönetiminde Yolsuzluklar, Nedenleri, Zararları ve Çözüm Önerileri, Sayıştay Araştırma Sayıştay Araştırma Dizisi, http://www.sayistay.gov.tr/yayin/yayinicerik/ aras27TKYYolsuz.pdf.

Shanker, Melissa C. ve Astrachan. Joseph H., (1996) Myths and Realities: Family Businesses Contribution to the US Economy -A Framework for Assessing Family Business Statistics, Family Business Review, 9 (2), ss. 107-123

Tarı, Recep (2008). Ekonometri, Gözden Geçirilmiş 5. Baskı, İzmit: Kocaeli Üniversitesi Yayınları No: 172.

Peelle, Henry E. (2007) Reciprocating Perceived Organizational Support through Citizenship Behaviors, Journal of Managerial Issues; Winter 19, 4, ss. 554575.

Williams, Steve, Pitre Richard, Zainuba, Mohamed. (2002), Justice and Organizational Citizenship Behavior Intentions: Fair Rewards Versus Fair Treatment, Journal of Social Psychology, 142 (1), ss. 33-44.

Wong, Linda C. ve Kleiner, Brian H. (1994), Nepotism, Work Study, Vol. 43 No. 5, ss. 10-12, 
